\title{
Bulk density and porosity of soils influenced by skidding operations in the Nkrankwanta Off-Forest Reserve of Ghana
}

\author{
Ammal Abukari ${ }^{1 *}{ }^{*}$, Donkor Christian ${ }^{l}$, Kwame Ochire-Boadu ${ }^{l}$ \\ ${ }^{1}$ Department of Forestry and Forest Resources Management, Faculty of Natural Resources and Environment, University for Development \\ Studies, Nyankpala Campus. Post office box TL1882, Tamale, Northern Region, Ghana-West Africa
}

\section{Original Article \\ *Corresponding author: aammal@uds.edu.gh}

Keywords:

Porosity

Bulk density

Compaction

Skidding

Palavras-chave:

Porosidde

Densidade aparente

Compactação

Derrapagem

Received in

2019/12/20

Accepted on

2021/07/01

Published in

2021/03/20

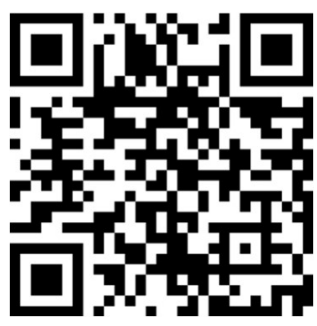

DOI: http://dx.doi.org/ 10.34062/afs.v8i2.9530

\section{(cc) BY}

ABSTRACT: Heavy forest machinery used in skidding can influence the physical properties of soils. These may lead to an upsurge in soil disruption and compaction of the soil surface decreases forest soil fertilities. This study assesses the effects of skidding on some soil physical properties such as the soil bulk density and porosity in the Nkrankwanta off-forest reserve in Ghana. The treatments comprised of four traffic intensity levels $(0,1$, 5, 10, and 15 passes) of the Mercedes Benz skidder (MB) Trac 1800 and a slope of two levels (less than $20 \%$ and greater than $20 \%$ ) in a completely randomized block design. Also, porosity and soil bulk density was assessed at varying distances from the MB Trac 1800. Soil bulk density results showed increasing trends with traffic frequency. Soil bulk density measured in the undisturbed area was $0.64 \mathrm{~g} \mathrm{~cm}^{-3}$ and $0.56 \mathrm{~g} \mathrm{~cm}^{-3}$ at slopes of less than $20 \%$ and greater than $20 \%$, respectively. On the skid trail, soil bulk density significantly increased with traffic frequency $(p<0.05)$. However, soil porosity declined. Soil porosity estimated in uninterrupted area was $59.10 \%$ and $57.40 \%$ at $<20 \%$ and $>$ $20 \%$ slope, respectively. Soil porosity was significantly influenced via different skidder passes $(p<0.05)$. The soil physical properties were not influenced by the steepness of the slope however acted together in the number of passes to influence soil porosity. The impacts of the skidder on soil physical properties were significantly apparent at distances of $2 \mathrm{~m}$ to each sideway of the skidding trail. In conclusion, distinct responsiveness ought to be considered throughout the operations of skidding to curtail unfriendly influences on soil physical properties in ground-based skidding.

\section{Densidade aparente e porosidade de solos influenciados por operações de arraste na Reserva Florestal Nkrankwanta de Gana}

RESUMO: O maquinário florestal pesado usado no arraste pode influenciar as propriedades físicas dos solos. Isso pode levar a um aumento na degradação do solo e a compactação da superfície do solo diminui a fertilidade do solo da floresta. Este estudo avalia os efeitos da derrapagem em algumas propriedades físicas do solo, como a densidade do solo e a porosidade na reserva Nkrankwanta fora da floresta em Gana. Os tratamentos consistiram em quatro níveis de intensidade de tráfego $(0,1,5,10$ e 15 passes) do skidder Mercedes Benz (MB) Trac 1800 e uma inclinação de dois níveis (menor que $20 \%$ e maior que $20 \%$ ) em um desenho de blocos completamente aleatorizados. Além disso, a porosidade e a densidade do solo foram avaliadas em distâncias variáveis do MB Trac 1800. Os resultados da densidade do solo mostraram tendências crescentes com a frequência do tráfego. A densidade do solo medida na área não perturbada foi de $0,64 \mathrm{~g}$ cm-3 e 0,56 g cm- 3 em declives de menos de $20 \%$ e maiores de $20 \%$, respectivamente. $\mathrm{Na}$ trilha de arraste, a densidade do solo aumentou significativamente com a freqüência de tráfego $(p<0,05)$. No entanto, a porosidade do solo diminuiu. A porosidade do solo estimada em área ininterrupta foi de $59,10 \%$ e $57,40 \%$ em $<20 \%$ e $>20 \%$ de declive, respectivamente. A porosidade do solo foi significativamente influenciada por diferentes passagens do skidder $(p<0,05)$. As propriedades físicas do solo não foram influenciadas pela declividade da encosta, porém atuaram conjuntamente no número de passadas influenciando a porosidade do solo. Os impactos do skidder nas propriedades físicas do solo foram significativamente aparentes a distâncias de $2 \mathrm{~m}$ para cada lado da trilha de arraste. Em conclusão, a capacidade de resposta distinta deve ser considerada ao longo das operações de arraste para reduzir as influências adversas nas propriedades físicas do solo em arraste com base no solo. 


\section{Introduction}

The usage of heavy equipment to execute forestry undertakings for example logging has intensified all over the overworld in the past years. Yet, this equipment could extremely influence the ecosystem of soils by way of inducing the upper soil layers as well as soil compaction (Najafi and Solgi 2010; Ampoorter et al. 2010; Picchio et al. 2019; Sohrabi et al. 2020). Soil compaction is a common consequence of the ground-based skidding systems that always occurred in heavy machinery operation (Binkley and Fisher 2013).

Soltanpour and Jourgholami (2013) detailed that the using heavy machinery and harvesting operation in the forested areas, naturally impact the bulk density of soils, degraded soil particles, decrease the porosity of soils and the porousness capability of soils, and as well as affecting the structure and the stability of soils thus triggering erosion.

The degradation of soil leads to the decline in total soil porosity, decrease in soil macro-porosity, reduce spore connectivity, increases shear strength and soil density (Solgi et al. 2013). The compaction of soil can lead to a decline in exchangeable gasses through the atmosphere and movement of water and gases via the soil, accordingly reducing nutrients, water, and oxygen to the roots (Frey et al. 2009). Decreases in soil porosity and air permeability decrease the extension and root penetration roots and consequently decrease the accessibility of roots to the uptake of water and nutrients (Botta et al. 2007). The declined growth of roots triggered via the compaction of soil leads to inadequate nutrients and water together with a lower photosynthetic rate (Cambi et al. 2017).

In Ghana, forest lands are largely situated in areas containing mountains and wood extraction at the ground base remains the commonly used technique for harvesting. Yet the main attention of woodlands is found in the southern parts of Ghana. In these areas, farm machines such as tractors and skidders are normally used for skidding operations and the majority of the machines used are of substantial weight. The passageway of these heavy machines can lead to adverse changes in forest soil structures (Ampoorter et al. 2007; Allman et al. 2015) consequently, there are greater potentials for the compaction of soils in forest operations (Cambi et al. 2016).
Skidding machinery is extensively utilized in automated forest harvesting operations and these machines influence soil physical proprieties (Solgi and Najafi 2014). So far, individual skidder type differs in automated features, such as width and height, diverse configurations of the front axle to the front of the machine and of the front axle to the blade cutting-edge arc, all of which can impact soil physical proprieties in different ways (Macrì et al. 2016).

The point to which compaction occurs in forest soil as a result of automated logging relies on numerous variables and features of the forest such as the soil texture, soil organic matter content, slope, soil water content, soil temperature, and harvesting activity such as the machine type, machine mass, traffic intensity (Mohieddinne et al. 2019). The number of machine passes is a factor that significantly influences the degree of soil damage.

In this study, the researchers aimed to evaluate the impact of the Mercedes Benz (MB) Trac 1800 skidder on the disruption of soils at altered the number of passes and trail slope in respect to the soil porosity and bulk density of soil. The ultimate goal of the researcher was to make available valuable, technical, and scientific evidence for the progress of best practices of management in the forest areas of Ghana with regards to the protection of forest soils efficiency and the effectiveness of the forest ecosystem.

\section{Materials and Methods \\ Site description}

This work was done throughout March-May 2018 in the Nkrankwanta Off-Forest Reserve in the Dormaa Municipal of Ghana in the Brong - Ahafo Region. The town elevation is about 375 meters above sea level. It is found within longitudes $3^{\circ}$ West and $3^{\circ}$ $30^{\prime}$ 'West and latitudes $7^{\circ}$ North and $7^{\circ} 30^{\prime}$ 'North. The yearly mean precipitation is between $125 \mathrm{~mm}$ and $175 \mathrm{~mm}$. The onset of the rains is from May to June with the heaviest precipitation in June whereas the second onset of the rains is from September to October. The yearly mean temperature is $26.1{ }^{\circ} \mathrm{C}$. The dominant species of trees in the reserves comprise, Milicia excelsa, Terminalia superba and Tectona grandis. The type of soil in the study area was identified as sandy-clay-loam soil. 
Ammal Abukari et al.

$\operatorname{tr}$

Figure 1. Map of the study area

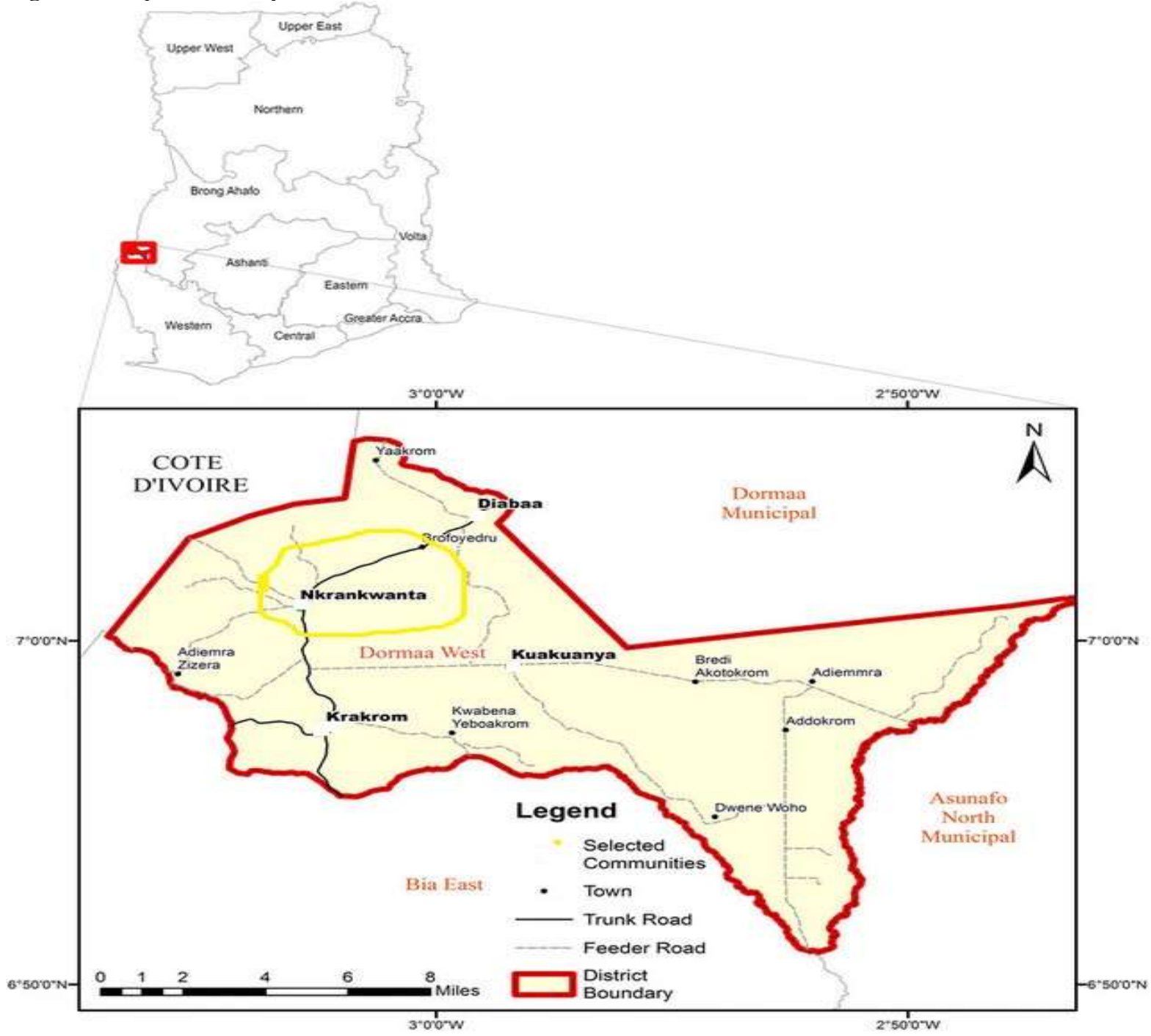

Machine description

The machine used in the study was the Mercedes Benz (MB) Trac 1800 skidder, which is powered by a 6-liter turbocharged diesel 6-cylinder engine. This machine has a slightly longer wheelbase, meaning more stability (Figure 1 and Table 1). 


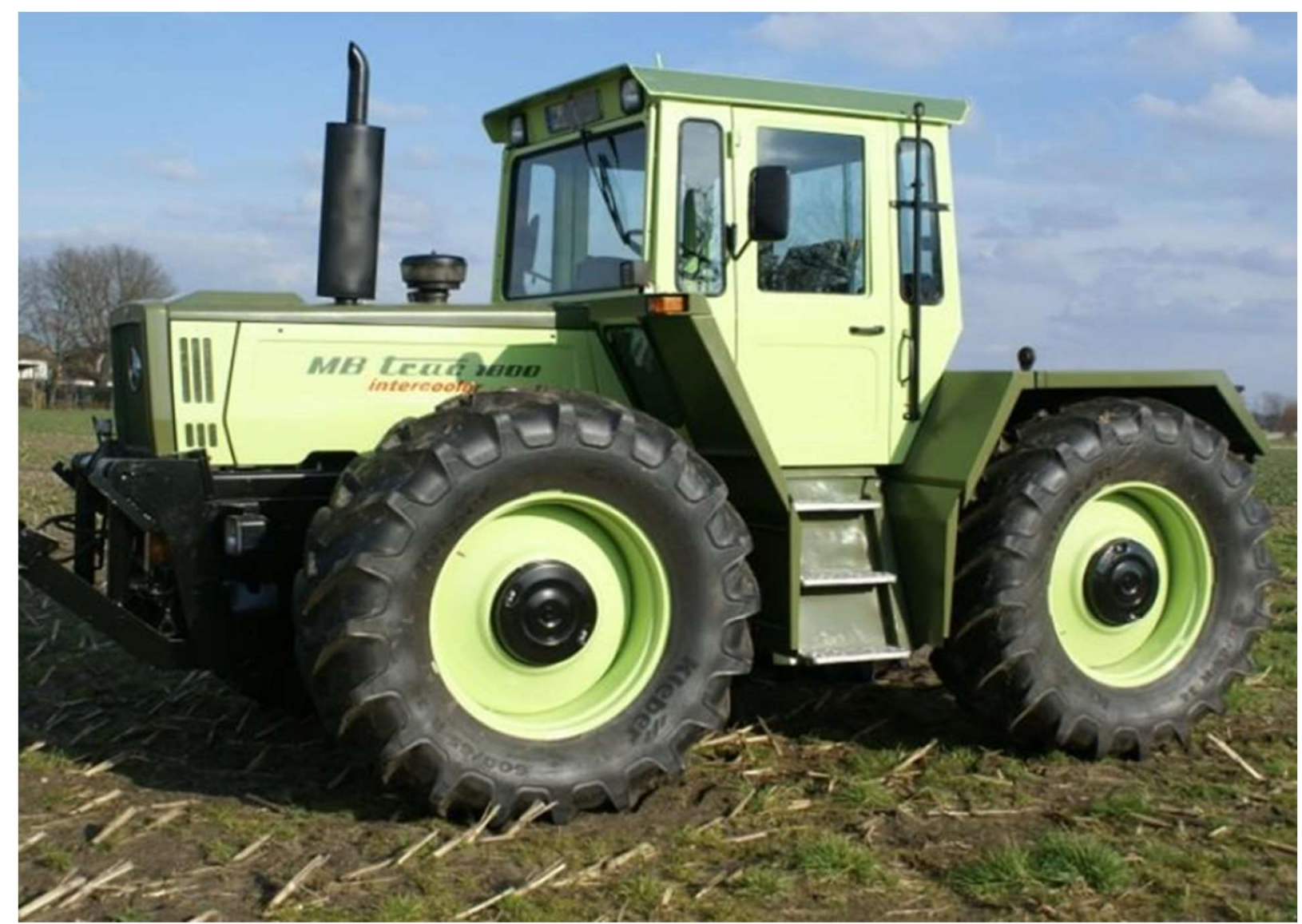

Figure 2. The MB Trac 1800 skidder used for skidding operations

Table 1. Measurement of skidder MB Trac 1800

\begin{tabular}{|l|l|l|}
\hline Features & Measurement Unit & Value \\
\hline Standard engine & $\mathrm{L}$ & Mercedes Benz 6.0 \\
\hline Power & $\mathrm{kW}$ & 134 \\
\hline Transmission & - & 14 forward; 14 reverse \\
\hline Height & $\mathrm{Cm}$ & 293 \\
\hline Width & $\mathrm{Cm}$ & 468 \\
\hline Maximum Blade Lift Above Ground & $\mathrm{Mm}$ & 1204 \\
\hline Maximum Blade Dig Below Ground & $\mathrm{Mm}$ & 295 \\
\hline Front Axle to Front of Machine & $\mathrm{Mm}$ & 1507 \\
\hline Front Axle to Blade Cutting-Edge Arc & $\mathrm{Mm}$ & 2112 \\
\hline Length & $\mathrm{Cm}$ & 468 \\
\hline Wheelbase & $\mathrm{Cm}$ & 265 \\
\hline Weight & $\mathrm{Kg}$ & $6351 \mathrm{~kg}$ \\
\hline Tire size & - & Back 18.4R34 \\
& & Front 18.4R34 \\
\hline
\end{tabular}

\section{Data collection technique and experimental design} Line transect space of $4.5 \mathrm{~m}$ wide and $100 \mathrm{~m}$ long were used to collect data of disturbed soils. The bulk density and porosity at slopes of different levels (less than 20\% and greater than 20\%) and different passes of $0,1,5,10$, and 15 in a completely randomized design with three replications to make a total of 24 plots. It was related to undisturbed areas and of no skidding influence, by $50-60 \mathrm{~m}$ from the skid trail, as in similar studies (Jaafari et al. 2014). Samples of soils at the depth of $0-10 \mathrm{~cm}$ were gathered at three varied points sideways of a different transect, the right track (RT), the middle of the tracks (MT), and the left track (LT). Additionally, samples of soils at 10 locations were collected on different sides of the track at an interval of $0.5 \mathrm{~m}$, covering the area of skid trails to undisturbed soils. The samples of soil were collected via a $50 \mathrm{~mm}$ high Eijkelkamp steel cylinders (72 $\mathrm{mm}$ 


\section{Ammal Abukari et al}

diameter), consequently, the samples of soils were free from grits and were put in labeled polyethylene bags. Samples of soils were also analyzed to determine the porosity and bulk density of soils using the bulk density core. Soils were compared before and after the study using a paired t-test.

Soil porosity was calculated based on (Solgi and Najafi 2014) as;

$\mathrm{AP}=(1-\mathrm{Db} / 2.65) / \mathrm{VC}$

Where:

AP - soil porosity

$\mathrm{Db}$ - soil bulk density

2.65 - assumed particle density

$\mathrm{VC}$ - volume of the soil cores $\left(502.4 \mathrm{~cm}^{3}\right)$
Volumes of soil cores were put into a $120{ }^{\circ} \mathrm{C}$ oven and dried for at least 48 hours. Bulk density was determined by dividing dry weight by the sample volume (Ezzati et al. 2012). The individual treatment was repeated five times.

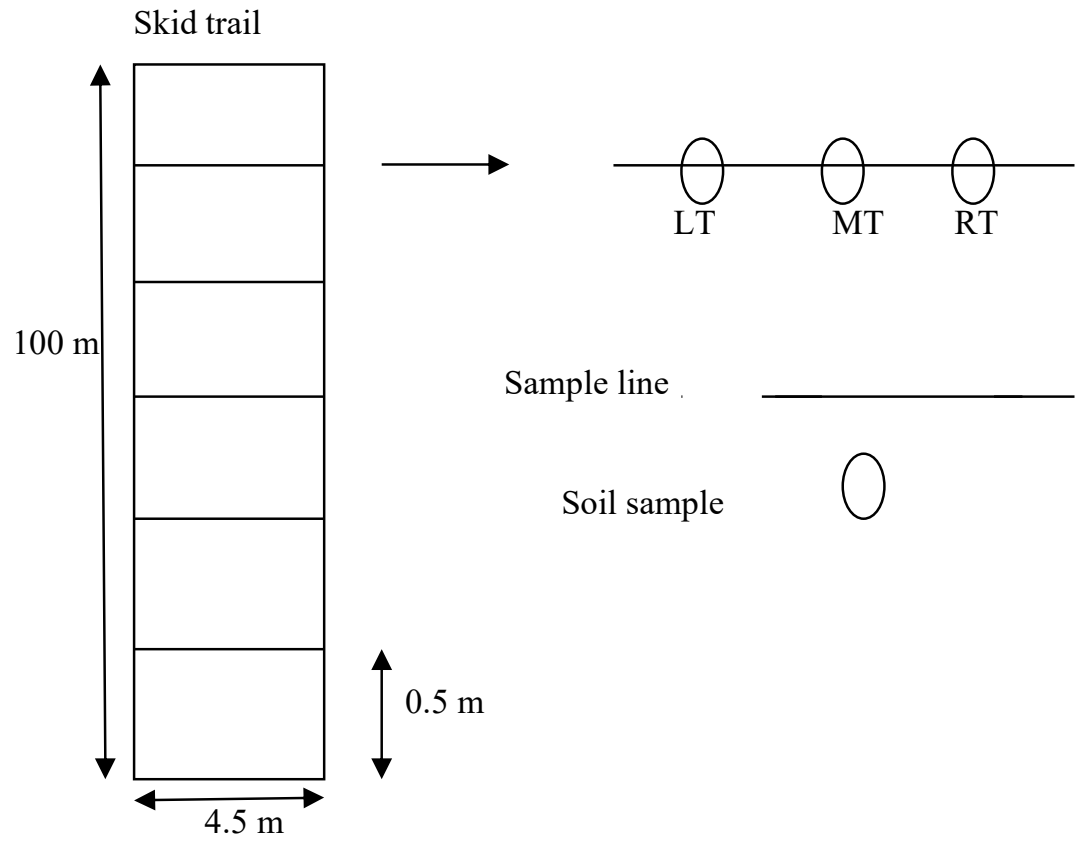

Figure 3. Arrangements of sample lines within plots

\section{Statistical analysis}

The influence of the levels of traffic, trail slope, soil porosity, and bulk density plus the interaction of the number of passes and slopes were assessed using a two-way ANOVA which was analyzed with GenStat 8 . The significant differences of porosity and soil bulked density was among various treatments using Turkey's test $(p<0.05)$.

\section{Results and discussion}

Soil bulk density measured in the undisturbed area was $0.64 \mathrm{~g} \mathrm{~cm}^{-3}$ and $0.56 \mathrm{~g} \mathrm{~cm}^{-3}$ at slopes of less than $20 \%$ and greater than $20 \%$, respectively. On the skid trail, soil bulk density significantly increased with traffic frequency $(p<0.05)$, following previous studies (Labelle and Jaeger 2011). Most of the potential impact occurred after the initial passes, also confirming the results of Solgi and Najafi (2014).

In contrast, slope did not impact soil bulk density (Table 2). This result was different from that found in previous studies (Jaafari et al. 2016), but can likely be explained by the larger tire size of the (MB) Trac 1800 skidder, which can reduce the impact on soil bulk density on different slopes. The effect of the interaction of the number of passes and slope was not found to be significant (Table 2).

Additionally, the force lowers speed intensely and increases the disruption of soils on steep slope trails (Solgi and Najafi 2014). Previous studies by Solgi et al. (2015) have recognized wheel slips on farm trucks triggering compaction significantly as well as wheel slip from forest trucks can consequently add to compaction. Compaction can also be expressed as the increased bulk density, accordingly at the initial passes.

Bulk density increases and porosity decreases on steep slope trails and at different distances from the trail and this could be connected to the lesser speed of the skidder on steep slopes.

An earlier investigation has only evaluated the effects of skidder operations on soil proprieties 
within the skid trail (Solgi and Najafi 2014; Naghdi et al. 2018). The researchers measured skidder impacts on soil properties beyond the left and right tracks. The researchers found out that the degree of soil bulk density at the right and left track or between tracks varied at different distances from the track. Indeed, the utmost bulk density of soil was perceived in the sample points along the main track as the researcher moved from the main track, bulk density decreased.

Soil porosity estimated in uninterrupted area was 59.10 and $57.40 \%$ at $<20 \%$ and $>20 \%$ slope, respectively. Soil porosity was significantly influenced via different skidder passes $(p<0.05)$ however the slope did not influence soil porosity
(Table 3). Specifically, soil porosity was considered lower in the undisturbed area on skidder trails. This could be due to the consequence of increased soil compaction leading to changes in soil porosity. Our findings showed that compaction led to the decrease in total porosity, probably owing to reduced macroporosity that was sturdily decreased at $>20 \%$ slope in some treatments. This result was partially confirmed by Solgi and Najafi (2014). The collaboration between different skidder passes and the slope was significantly influenced $(p>0.05)$ and the decrease of the soil porosity was further noticeable at $>20 \%$ slope (Table 3 ). At different treatment from the main track increased soil total porosity.

Table 2. Effect of slope and traffic intensity on soil bulk density $\left(\mathrm{g} \mathrm{cm}^{-3}\right)$

\begin{tabular}{|l|l|l|l|l|}
\hline Statistic & Number of Passes (NP) & \multicolumn{2}{l|}{ Slope (S) } & Mean Number of Passes \\
\hline & & $<20$ & $>20$ & \\
\hline \multirow{3}{*}{$\begin{array}{l}\text { NP } 10.12^{* * *} \\
\text { S 0.119 }\end{array}$} & 0 & $0.64^{\mathrm{c}}$ & $0.56^{\mathrm{c}}$ & $0.58^{\mathrm{z}}$ \\
\cline { 2 - 5 } & 1 & $0.83^{\mathrm{b}}$ & $0.96^{\mathrm{b}}$ & $0.87^{\mathrm{s}}$ \\
\cline { 2 - 5 } & 5 & $0.95^{\mathrm{ab}}$ & $1.03^{\mathrm{ab}}$ & $0.98^{\mathrm{ky}}$ \\
\cline { 2 - 5 } & 10 & $1.23^{\mathrm{ab}}$ & $1.34^{\mathrm{ab}}$ & $1.28^{\mathrm{ky}}$ \\
\cline { 2 - 5 } & 15 & $1.32^{\mathrm{a}}$ & $1.36^{\mathrm{a}}$ & $1.33^{\mathrm{x}}$ \\
\cline { 2 - 5 } & Mean slope & $0.74^{\mathrm{B}}$ & $0.66^{\mathrm{B}}$ & - \\
\hline
\end{tabular}

Capital letters indicate significant differences among row means. Small letters indicate significant differences among column means.

Table 3. Effect of slope and the traffic intensity on soil total porosity (\%)

\begin{tabular}{|l|l|l|l|l|}
\hline Statistic & Number of Passes (NP) & \multicolumn{2}{l|}{ Slope $(\mathrm{S})$} & Mean Number of Passes \\
\hline & & $<20$ & $>20$ & \\
\hline \multirow{3}{*}{$\begin{array}{l}\text { NP 54.21 } \\
\text { S 4.18 }\end{array}$} & 0 & $57.40^{\mathrm{a}}$ & $59.10^{\mathrm{a}}$ & $58.19^{\mathrm{q}}$ \\
\cline { 2 - 5 } & 1 & $42.30^{\mathrm{b}}$ & $49.11^{\mathrm{b}}$ & $45.56^{\mathrm{q}}$ \\
\cline { 2 - 5 } & 5 & $41.28^{\mathrm{b}}$ & $48.49^{\mathrm{b}}$ & $44.95^{\mathrm{q}}$ \\
\cline { 2 - 5 } & 10 & $38.66^{\mathrm{b}}$ & $33.55^{\mathrm{c}}$ & $26.10^{\mathrm{p}}$ \\
\cline { 2 - 5 } & 15 & $32.17^{\mathrm{c}}$ & $30.49^{\mathrm{c}}$ & $21.33^{\mathrm{r}}$ \\
\cline { 2 - 5 } & Mean slope & $42.42^{\mathrm{B}}$ & $44.20^{\mathrm{B}}$ & - \\
\hline
\end{tabular}

Capital letters indicate significant differences among row means. Small letters indicate significant differences among column means.

\section{Conclusion}

This study was carried out with the general aim of describing the effects of skidder passes and skid trail slope on the bulk density and porosity of the soil in Ghana. As compaction increased, the rates of total porosity decreased. In particular, the results pointed out that traffic intensity (number of machines passes) plays an important role in forest soil compaction: soil deformation can increase with the number of passes and may lead to excessive soil disturbance. One pass of the skidder is enough to cause ruts classified as medium-heavy disturbance and to induce a significant increase in soil bulk density. Conversely, the two different classes of slope did not show significant effects on soil bulk density and porosity. The impact of the skidder on soil physical proprieties was more noticeable under the main track (right and left track) or log track (between tracks) than at various distances from the track. Successful planning of skidding operations to minimize soil compaction will depend on knowledge of the distribution of soils in the area to be managed, coupled with knowledge on the response of each soil to compaction effort. There is the need to comprehend the connection concerning the soils in the forest and their proneness to soil disruption from harvesting equipment.

\section{References}

Allman M, Jankovský M, Messingerová V, Allmanová Z, Ferenčík M (2015) Soil compaction of various Central European forest soils caused by traffic of forestry machines with various chassis. Forest systems, 24(3): 6.

Ampoorter E, Goris R, Cornelis WM, Verheyen K (2007) Impact of mechanized logging on compaction status of sandy forest soils. Forest Ecology and Management, 241: 162- 174. 
Binkley D, Fisher RF (2013) Ecology and management of forest soils. Wiley-Blackwell, Oxford

Botta G, Pozzolo O, Bomben M, Rosatto H, Rivero D, Ressia M, Tourn M. Soza E, Vázquez J (2007) Traffic alternatives in harvest of soybean (Glycine max L.): Effect on yields and soil under direct sowing system. Soil Tillage Res, 96: 145-154.

Cambi M, Hoshika Y, Mariotti B, Paoletti E, Picchio R, Venanzi R, Marchi E (2017)

Compaction by a forest machine affects soil quality and Quercus robur L. seedling performance in an experimental field. For. Ecol.Manag, 384: 406-414.

Cambi M, Grigolato S, Neri F, Picchio R, Marchi E (2016) Effects of Forwarder Operation on Soil Physical Characteristics: a Case Study in the Italian Alps. Croatian Journal of Forest Engineering, 37(2): 233-239.

Ezzati S, Najafi A, Rab MA, Zenner EK (2012) Recovery of soil bulk density, porosity and rutting from ground skidding over a 20 -year period after timber harvesting in Iran. Silva Fennica, 46(4): 521538.

Frey B, Kremer J, Rüdt A, Sciacca S, Matthies D, Lüscher P (2009) Compaction of forest soils with heavy logging machinery affects soil bacterial community structure. Eur. J. Soil Biol, 45: 312-320.

Jaafari A, Najafi A, Zenner EK (2014) Groundbased skidder traffic changes chemical soil properties in a mountainous Oriental beech (Fagus orientalis Lipsky) forest in Iran. Journal of Terramech, 55: 39-46.

Labelle ER, Jaeger D (2011) Soil compaction caused by cut-to-length forest operations and possible shortterm natural rehabilitation of soil density. Soil Science Society of America Journal, 75: 2314-2329.

Macrì G Russo D, Zimbalatti G, Proto AR (2016) Measuring the mobility parameters of tree-length forwarding systems using GPS technology in the Southern Italy forestry. Agronomy Research,14(3): 836-845.

Mohieddinne, H., Brasseur, B., Spicher, F., GalletMoron, E., Buridant, J., Kobaissi, A., \& Horen, H. (2019). Physical recovery of forest soil after compaction by heavy machines, revealed by penetration resistance over multiple decades. Forest Ecology and Management, 449: 117472.

Najafi A, Solgi A (2010) Assessing site disturbance using two ground survey methods in a mountain forest. Croatian Journal of Forest Engineering, 31(1): 47-55

Naghdi R, Solgi A, Zenner E, Behjou FK (2018) Soil physical properties degrade further on skid trails in the year following operations. Journal of Forestry Research, 29(1): 93-101. https://doi.org/10.1007/s11676-017-0413-8.

Nawaz MF, Bourrie G, Trolard F (2013) Soil compaction impact and modelling. A review. Agronomy for sustainable development, 33(2): 291309.

Picchio R, Venanzi R, Tavankar F, Luchenti I, Bodaghi A.I, Latterini F, Nikooy M, Di Marzio N, Naghdi R, (2019) Changes in soil parameters of forests after windstorms and timber extraction. European Journal of Forestry Resources, 138:875888. https://doi.org/10.1007/s10342-019-01210-5

Sohrabi H, Jourgholami M, Jafari M, Shabanian N, Venanzi R, Tavankar F, Picchio R (2020) Soil Recovery Assessment after Timber Harvesting Based on the Sustainable Forest Operation (SFO) Perspective in Iranian Temperate Forests. Sustainability, 12, 2874.

Solgi A, Najaf A, Sam Daliri H (2013) Assessment of Crawler Tractor Effects on Soil Surface Properties. Casp. Journal of Environmental Science, 11: 185-194.

Solgi A, Najafi A (2014) The impacts of groundbased logging equipment on forest soil. Journal of Forestry Science, 60: 28-34.Solgi A, Najafi A, Ezzati S, Feren cík M (2016) Assessment of groundbased skidding impacts on the horizontally rate and extent of soil disturbance along the margin of the skid trail. Annals of Forest Science, 73: 513-522.

Solgi A, Naghdi R, Petros A, Tsioras MN (2015) Soil Compaction and Porosity Changes Caused During the Operation of Timberjack 450C Skidder in Northern Iran. Croatian Journal of Forest Engineering, 36(2): 217-225.

Soltanpour S, Jourgholami M (2013) Soil bulk density and porosity changes due to ground-based timber extraction in the Hyrcanian forest. Notulae Scientia Biologicae, 5(2): 263-2 